\title{
Biological Control of Tomato Phytopathogens as an Alternative to Agricultural Defensives and Antibiotics
}

\author{
Rodolfo Sodré Tavares'; Paulo Alex Neves da Silval; Ludmila Batista Machado²; Abadia dos Reis \\ Nascimento ${ }^{3}$; Lilian Carla Carneiro'; José Daniel Gonçalves Vieiral
}

$\triangle$ free_flying@ohotmail.com

1. Universidade Federal de Goiás, Setor Leste Universitário, Goiânia - GO

2. Pontifícia Universidade Católica de Goiás, Setor Leste Universitário, Goiânia - GO

3. Universidade Federal de Goiás, Escola de Agronomia, Goiânia - GO

Histórico do Artigo: 0 autor detém os direitos autorais deste artigo.

Recebido em: 13 de janeiro de $2021 \quad$ Aceito em: 24 de maio de $2021 \quad$ Publicado em: 31 de dezembro de 2021

\begin{abstract}
The tomato (Solanum lycopersicum L.) is one of the most cultivated vegetable in the world. China represents about $25 \%$ of all world production, so there is a dependence and constant use of agricultural defensives in tomato crops. The application of chemical products banned in many parts of the world has as a side effect a major impact on human health and the ecosystem, therefore necessary to adopt other disease prevention strategies. Another method of combating tomato disease is the use of microorganisms as a form of biological control, which is considered an alternative to agricultural defensives and antibiotics offering better sustainability and less toxicity. In this work, the agricultural defensives most used by producers were, Pyraclostrobin, Mancozebe, Copper oxychloride, and derivatives of DDT. For the antibiotics, Streptomycin and 0xytetracycline were the most used, whereas Bacillus spp. and Lactic Acid Bacteria (LAB) was the microorganisms most cited as a form of biological control. Lastly the main phytopathogens of tomato were Xanthomonas spp., Clavibacter michiganensis subsp. michiganensis and Ralstonia solanacearum. The objectives of this work were to identify the main types of agricultural defensives, antibiotics and genera of microorganisms used to control tomato diseases and to compare their impact on human health and the environment.
\end{abstract}

Keywords: Tomato disease, Phytopathogens, Lactic acid bacteria, Agricultural defensive, Biological control.

\section{Controle Biológico de Fitopatógenos do Tomate como Alternativa a Defensivos Agrícolas e Antibióticos}

Resumo: 0 tomate (Solanum lycopersicum L.) é uma das hortaliças mais cultivadas do mundo. A China representa cerca de $25 \%$ de toda a produção mundial, desta forma existe uma dependência e uso constante de defensivos agrícolas na cultura do tomate. A aplicação de produtos químicos proibidos em diversas partes do mundo tem como efeito colateral um grande impacto na saúde humana e no ecossistema, sendo necessário adotar outras estratégias de prevenção de doenças. Outra forma de combate às doenças do tomateiro é a utilização de microrganismos como forma de controle biológico, considerado uma alternativa aos defensivos agrícolas e antibióticos com maior sustentabilidade e menor toxicidade. Neste trabalho, os defensivos agrícolas mais utilizados pelos produtores foram Piraclostrobina, Mancozebe, Oxicloreto de Cobre e derivados do DDT. Para os antibióticos, Estreptomicina e Oxitetraciclina foram os mais utilizados, enquanto Bacillus spp. e bactérias do ácido lático (BAL) foram os microrganismos mais citados como forma de controle biológico. Por fim, os principais fitopatógenos do tomateiro foram Xanthomonas spp., Clavibacter michiganensis subsp. michiganensis e Ralstonia solanacearum. 0s objetivos deste trabalho foram identificar os principais tipos de defensivos agrícolas, antibióticos e gêneros de microrganismos utilizados no controle de doenças do tomateiro e comparar seu impacto na saúde humana e no meio ambiente.

Palavras-chave: Doença do tomateiro, Fitopatógenos, Bactéria ácido láctica, Defensivo agrícola, Controle biológico. 


\section{Control Biológico de Fitopatógenos del Tomate como Alternativa a Defensivos Agrícolas y Antibióticos}

Resumen: El tomate (Solanum lycopersicum L.) es una de las hortalizas más cultivadas del mundo. China representa alrededor del $25 \%$ de toda la producción mundial, por lo que existe una dependencia y uso constante de defensivos agrícolas en los cultivos de tomate. La aplicación de productos químicos prohibidos en muchas partes del mundo tiene como efecto secundario un gran impacto en la salud humana y el ecosistema, por lo que es necesario adoptar otras estrategias de prevención de enfermedades. Otro método para combatir las enfermedades del tomate es el uso de microorganismos como forma de control biológico, que se considera una alternativa a los defensivos agrícolas y los antibióticos que ofrece una mayor sostenibilidad y menor toxicidad. En este trabajo, los defensivos agrícolas más utilizados por los productores fueron Pyraclostrobin, Mancozebe, Oxicloruro de cobre y derivados del DDT. Para los antibióticos, la Estreptomicina y la 0xitetraciclina fueron las más utilizadas, mientras que Bacillus spp. y las bacterias del ácido láctico (BAL) fueron los microorganismos más citados como forma de control biológico. Por último, los principales fitopatógenos del tomate fueron Xanthomonas spp., Clavibacter michiganensis subsp. michiganensis y Ralstonia solanacearum. Los objetivos de este trabajo fueron identificar los principales tipos de defensivos agrícolas, antibióticos y géneros de microorganismos utilizados para controlar las enfermedades del tomate y comparar su impacto en la salud humana y el medio ambiente.

Palabras clave: Enfermedad del tomate, Fitopatógenos, Bacterias del ácido láctico, Defensivo agrícola, Control biológico.

\section{INTRODUCTION}

The tomato (Solanum lycopersicum L.) is one of the most cultivated vegetable in the world (CASTR0; BRANDÃ0; MACED0, 2008). The main tomato-producing countries in the world in terms of production and exportation are China, India, United States of America (USA), Turkey, Egypt, Italy, Spain, and Brazil. China represents about 48 \% of all production when compared to the main producing countries, producing around 61.6 million megagrams in 2018 (Figure 1), (FA0STAT, 2020).

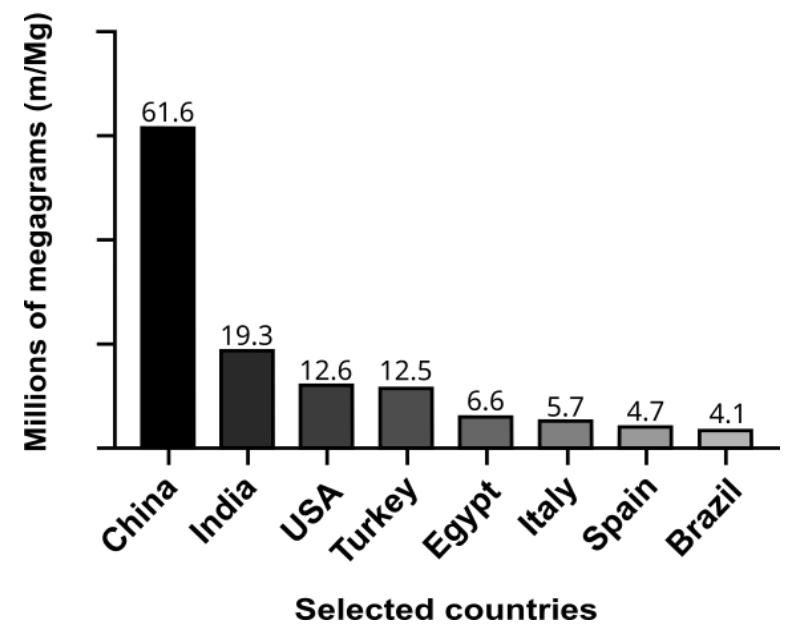

Figure 1 - The Asian continent represented by China and India represents about $80 \%$ of the world's tomato production. 1 megagram = 1 ton .

Source: The author himself. 
Biological Control of Tomato Phytopathogens as an Alternative to Agricultural Defensives and Antibiotics

The commercialization of tomato has a strong impact on the economy of several countries, but the susceptibility of some tomato cultivars, the environmental factors and agricultural practices that favor the occurrence of some diseases, making the tomato the target of several types of phytopathogens. On a worldwide scale, it is estimated that around $35 \%$ of production is directly affected, leading to a decrease in fruit quality and losses in the postharvest process. Due to the low resistance of the tomato, there is a dependence and the constant use of agricultural defensive in tomato crops (ZAVATTI; ABAKERLI, 1999; ENGINDENIZ, 2006).

In the beginning, agricultural defensives or pesticides had low solubility and strongly adhered to the soil, over the years and the improvement of technologies, these synthetics compounds became more and more soluble in water, adhering less and less to the soil and having a more volatile profile in compared to its first formulations, thus this technological innovation allowed the manipulation and creation of chemical compounds that are increasingly toxic and, as a side effect, possessing a high potential to cause damage to human health and the ecosystem (VEIGA et al., 2006; IZZEDDIN; MEDINA, 2011). As the main strategy to combat and prevent pests and diseases, agricultural defensives can also bring complications to the immune system, central and peripheral nervous systems, being associated with the appearance of various types of cancer. Brazil is one of the main countries that use agricultural defensives worldwide, having the approval of substances with different spectrum of fungicidal, acaricidal, herbicidal and bactericidal actions (CALDAS; SOUZA, 2000).

Other products, such as antibiotics, are used to control diseases in tomatoes, however the use of Streptomycin sulfate, copper-based antibiotics or combinations of these, do not always work satisfactorily, because when the disease caused by pathogens such as Clavibacter michiganensis subsp. michiganensis, which causes bacterial cancer and Xanthomonas pathovars, which causes tomato bacterial stain, chemical treatment is not very efficient, in addition to causing the selection of resistant strains (ITAKAR0 et al., 2015; XU et al., 2015).

Thus, the use of microorganisms as a form of biological control is considered an alternative to agricultural defensives, and antibiotics offering better sustainability and less toxicity (KONDOH; HIRAI; SHODA, 2000). Countries such as Sweden, Indonesia, Norway, Denmark, Holland and Guatemala are examples of countries that had an annual reduction of 35 to $75 \%$ in the use of agricultural defensives without a reduction in production, with emphasis on Indonesia that was successful in decreasing the amount of agricultural defensives and using biological control, obtaining a $12 \%$ increase in production over the years (WILSON; TISDELL, 2001). In this context, several strains are indicated in the fight against several tomato diseases, 
such as lactic acid bacteria (LAB), growth promoting Rhizobacteria, Trichoderma spp., Pseudomonas fluorescens, Bacillus spp., bacteriophages, among others. Therefore, the use of biological control is a viable option for agricultural defensives and antibiotics (SHOKRYAZDAN et al., 2017; GUIMARÃES et al., 2018; MARIN et al., 2019).

Thus, the objectives of this work were to identify the main types of agricultural defensive, antibiotics and genera of microorganisms used to control tomato diseases and to compare their impact on human health and the environment.

\section{MATERIALS AND METHODS}

This study is a systematic review of journals and indexed articles. The search was carried out between January 2020 and June 2020, when there was a search in the databases ScienceDirect, Pubmed / Medline and Scielo, without time delimitation.

The database search was performed as follows: in the ScienceDirect and Pubmed database, the keywords used were "Biological control", "Lactobacillus", "Antibiotic", "Tomato biological control", "Chemical control of tomato", "tomato disease", "Pesticides application and Tomato", "Probiotic bacteria", "Antibiotic and tomato", "Plant pathogens", "Phytopathogenic bacteria", "Animal", "Gen". For the Scielo database, the descriptors had to be adapted by the search engine limitation, only the last two descriptors were omitted. The following Boolean operators were used: OR, AND and NOT.

The inclusion criteria were published works and available entirely in scientific database in the online modality, works that address biological control using probiotic microorganisms (bacteria, fungi and viruses), use of pesticides or antibiotics as chemical methods as a way of control against tomato diseases. The exclusion criteria were studies that evaluate the control of tomato diseases using other methods, studies published as posters and articles that present inconclusive evaluations. The works that were considered eligible were read in full and the data available in the text were extracted according to the following criteria: Author, year of publication and control method used.

In addition to the databases mentioned, the database of the Brazilian Agricultural Research Corporation Ministry of Agriculture, Livestock and Supply (EMBRAPA), Ministry of Agriculture, Livestock and Supply (AGROFIT) and the National Health Surveillance Agency (ANVISA), were also consulted, which provide data and regulations on chemical and biological control in Brazil, were used as a research source. 
Biological Control of Tomato Phytopathogens as an Alternative to Agricultural Defensives and Antibiotics

\section{Selection of Articles}

The search carried out through the implementation of the protocol returned a total of 943 articles, of which 753 were excluded after the preliminary analysis. Of the remaining 190 articles, 31 did not meet the inclusion criteria. One hundred fifty-nine articles were selected for detailed analysis of the title and abstract and the inclusion and exclusion criteria were applied in parallel. One hundred thirty-one filtered articles were selected, and their texts were read in full. Finally, 40 studies were selected to be part of this review article. Figure 2 presents the summary of the search process for the articles.

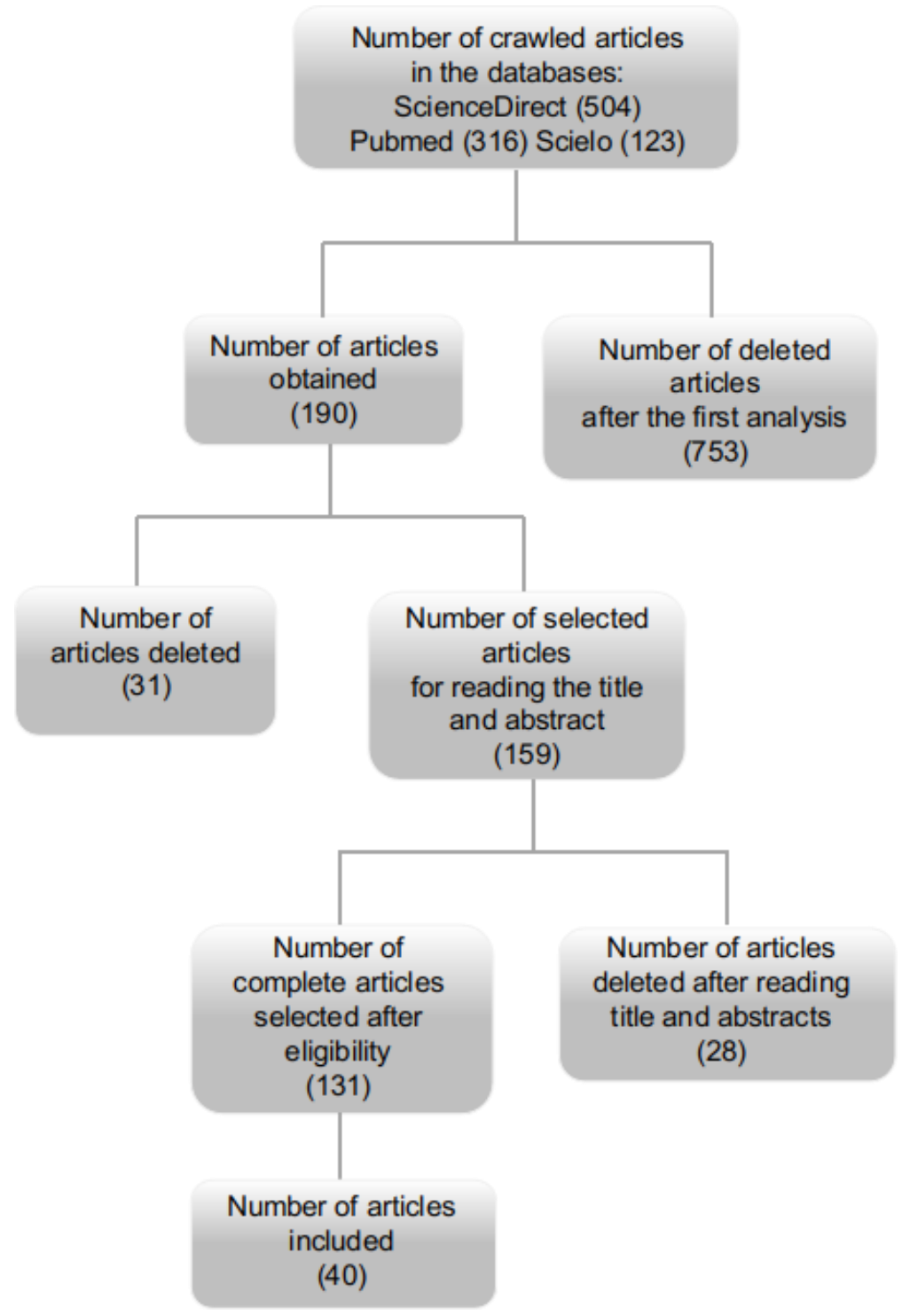

Figure 2 - Summary of the search process for articles.

Source: Adapted from Silva et al. (2019). 


\section{RESULTS AND DISCUSSION}

According to data released by EMBRAPA, agricultural defensives are classified by the ANVISA according to their degree of toxicity based on their acute effects.

These products are classified based on the lethal dose 50 (LD50), which has as a parameter the dose necessary to kill 50\% of the population of animals used in the experiments (often rats and mouse), in a period of approximately 2 weeks (BONVOISIN et al., 2020). For the Ministry of Health (MSB), agricultural defensives are based on the oral LD50 of liquid and solid formulations, while for the World Health Organization (WHO) the toxicological class is also based on the LD50, but in oral and dermal form, per $\mathrm{mg} / \mathrm{kg}$ of weight of liquid and solid formulations (ANVISA, 2019; BONVOISIN et al., 2020). Although the two entities present certain changes, in both cases agricultural defensives are classified as follows based on the LD50; Class I - extremely toxic (red band); class II - highly toxic (yellow band); class III - moderately toxic (blue band) and; class IV - little toxic (green band), (Table 1).

Table 1 - Acute oral, skin and inhalation toxicological classification (LD50)

\begin{tabular}{|c|c|c|c|c|c|}
\hline Class & & Class I & Class II & Class III & Class IV \\
\hline Degree of toxicity & & $\begin{array}{l}\text { Extremely } \\
\text { Toxic }\end{array}$ & Highly Toxic & Moderately Toxic & $\begin{array}{l}\text { Little } \\
\text { Toxic }\end{array}$ \\
\hline Assigned color & & Red & Yellow & Blue & Green \\
\hline \multirow[b]{2}{*}{ Oral exposure route } & unity & \multirow[b]{2}{*}{$\leq 5$} & \multirow[b]{2}{*}{$>5-50$} & \multirow[b]{2}{*}{$>50-300$} & \multirow[b]{2}{*}{$>300-2000$} \\
\hline & 1(mg/Kg p.c.) & & & & \\
\hline $\begin{array}{c}\text { Exposure route } \\
\text { cutaneous } \\
\end{array}$ & 1(mg/Kg p.c.) & $\leq 50$ & $>50-200$ & $>200-1000$ & $>1000-2000$ \\
\hline \multirow{2}{*}{ Inhalation exposure rou } & Gases $^{2}(\mathrm{ppm} / \mathrm{V})$ & $\leq 100$ & $>100-500$ & $>500-2500$ & $>2500-20000$ \\
\hline & Vapors ${ }^{3}(\mathrm{mg} / \mathrm{L})$ & $\leq 0,5$ & $>0,5-\leq 2,0$ & $>2,0-\leq 10$ & $>10 \leq 20$ \\
\hline
\end{tabular}

Toxicological classification attributed to different routes of exposure. Legend: 1. milligram of waste per kilogram of body weight, 2. parts per million of volume, 3. milligram per liter.

Source: National Health Surveillance Agency (ANVISA) (Adapted from ANVISA 2019).

It is worth mentioning that, due to the new regulatory framework for the use of agricultural defensives in Brazil, many products are in the process of being reclassified, nevertheless no change in the toxicity of the final product. The new regulatory framework brings, among other changes, an improvement of the information that reaches the rural producer, improving the product label with a more accessible language, aiming to mitigate the 

Antibiotics

negative impacts on health and the environment, thus making Brazil following the Globally Harmonized System of Classification and Labelling of Chemicals (GHS). Therefore, as a result of this transition phase, the classification by bands will be adopted (ANVISA, 2019).

The quantity and use of these agricultural defensives vary according to the demand of each producer and their classification according to the spectrum of action can be as follows; acaricide/fungicide, bactericide, adhesive spreader and fungicide according to the registration certificate (Table 2).

Table 2 - Main groups of agricultural defensives used in tomato plantations in Brazil

\begin{tabular}{|c|c|c|c|}
\hline Group & \multicolumn{3}{|c|}{ Acaricide/Fungicide } \\
\hline Commercial name & 'Uni & Active principle & Toxicological class/Legend \\
\hline Dithane WG NT & ${ }^{2} \mathrm{Kg}$ & mancozeb & I Extremely Toxic \\
\hline Manzate WG & $\mathrm{Kg}$ & mancozeb & I Extremely Toxic \\
\hline Gravun & $\mathrm{Kg}$ & cyprodinil & I Extremely Toxic \\
\hline Tradecorp 480 EC & ${ }^{3} \mathrm{~L}$ & chlorpyrifos & I Extremely Toxic \\
\hline Meothrim 300 & $\mathrm{~L}$ & fenpropathrin & I Extremely Toxic \\
\hline Terrazole $350 \mathrm{WP}$ & $\mathrm{Kg}$ & etridiazole & I Extremely Toxic \\
\hline Mancozebe CCAB & $\mathrm{Kg}$ & mancozeb & II Highly Toxic \\
\hline Abamectin Nortox & $\mathrm{Kg}$ & abamectin & II Highly Toxic \\
\hline Thiodan CE & $\mathrm{L}$ & endosulfan & II Highly Toxic \\
\hline Evolution & $\mathrm{Kg}$ & acefato & III Moderately Toxic \\
\hline Pirate & $\mathrm{L}$ & chlorfenapyr & III Moderately Toxic \\
\hline Vertimec $18 \mathrm{EC}$ & $\mathrm{L}$ & abamectin & III Moderately Toxic \\
\hline Assist & $\mathrm{L}$ & mineral oil & IV Low Toxic \\
\hline Group & \multicolumn{3}{|c|}{ Bactericide } \\
\hline Commercial name & Uni & Active principle & Toxicological class/Legend \\
\hline Scooter & Kg & mancozeb + copper oxychloride & I Extremely Toxic \\
\hline Kocide Bioactive & $\mathrm{Kg}$ & copper oxychloride & III Moderately Toxic \\
\hline Cobre Atar BR & Kg & cuprous oxide & IV Low Toxic \\
\hline Reconil & $\mathrm{L}$ & copper oxychloride & IV Low Toxic \\
\hline Recop & $\mathrm{Kg}$ & copper oxychloride & IV Low Toxic \\
\hline Group & \multicolumn{3}{|c|}{ Adhesive spreader } \\
\hline Commercial name & Uni & Active principle & Toxicological class/Legend \\
\hline Adesil & $\mathrm{L}$ & ethoxylated nonylphenol & I Extremely Toxic \\
\hline Group & \multicolumn{3}{|c|}{ Fungicide } \\
\hline Commercial name & Uni & Active principle & Toxicological class/Legend \\
\hline Cercobin $700 \mathrm{WP}$ & Kg & thiophanate-methyl & I Extremely Toxic \\
\hline Forum Plus & $\mathrm{Kg}$ & dimethomorph & I Extremely Toxic \\
\hline Galben-M & $\mathrm{Kg}$ & benalaxyl + mancozeb & I Extremely Toxic \\
\hline Orthocide-500 & $\mathrm{Kg}$ & captan & I Extremely Toxic \\
\hline Thiobel 500 & Kg & cartap hydrochloride & I Extremely Toxic \\
\hline Bravonil Ultrex & $\mathrm{Kg}$ & chlorothalonil & I Extremely Toxic \\
\hline Daconil WG & Kg & chlorothalonil & I Extremely Toxic \\
\hline Folio Gold $440 \mathrm{SC}$ & Kg & chlorothalonil + metalaxyl-M & I Extremely Toxic \\
\hline
\end{tabular}

Main classes of agricultural defensives and their toxicological classification, where most agricultural defensives used in tomato plantations in Brazil vary between classes I, III and IV. *For a better comparison consider $1 \mathrm{Kg}=1 \mathrm{~L}$. Legend: 1. Unit, 2. Kilogram, 3. Liter.

Source: Adapted from Brazilian Agricultural Research Corporation Ministry of Agriculture, Livestock and Supply EMBRAPA 2008. 
According to the data presented in Table 2, it was possible to measure the most used agricultural defensives in tomato plantations according to classification and their degree of toxicity (Figure 3).

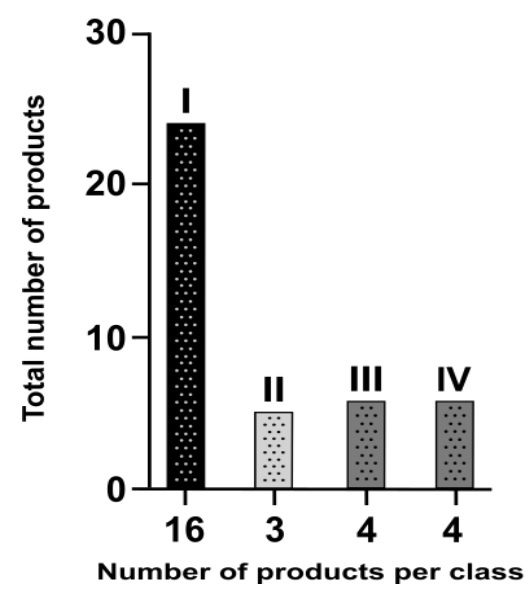

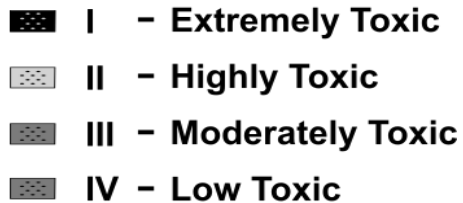

IV - Low Toxic

Figure 3 - Classes of agricultural defensives used in the cultivation of tomatoes. Source: The author himself.

Despite a large number of chemical products intended to combat tomato diseases, there are several alternatives to agricultural defensives, in this sense some of the products used as a form of biological control are shown in (Table 3) (BETTIOL et al., 2012; SOLANKI et al., 2015).

Table 3 - Main biological control agents used in tomato plantations in Brazil and worldwide

\begin{tabular}{llc}
\hline Commercial name & Active principle & Registration/marketing \\
\hline Nemata & Paecilomyces lilacinus DSM 15169 & Colombia \\
Agrotrich and Agrotrich Plus & Trichoderma spp ${ }^{1}$ (6x) & Brazil (temporary registration) \\
EC0-77 & Trichoderma harzianum cepa B77 & South Africa, Kenya and Zambia \\
Ecotrich ES & Trichoderma harzianum & Brazil (temporary registration) \\
Sentinel - Trichoprotection & Trichoderma atroviride LC52 & New Zealand \\
Trichodel & Trichoderma spp. & Brazil \\
Trichonativa & Trichoderma virens cepa Sherwood & Chile \\
& Nativa, Trichoderma harzianum & \\
& cepa Queule Nativa e Trichoderma & \\
& parceanamosum cepa Trailes & \\
Trichozam & Nativa & Honduras \\
Amylo-X & Trichoderma spp. & Italy \\
Botrybell & Bacillus amyloliquefaciens subsp. & \\
Nacillus & plantarum D747 & Epain \\
RhizoVital & Bacillus velezensis & Chile \\
\hline
\end{tabular}

Main microorganisms used in biological control specifically for tomato. Botrybell and Bacillus products are specifically for phytopathogens. Brazil has three products, two of which have only temporary registration. Legend: 1. six different strains of Trichoderma.

Source: Adapted from Brazilian Agricultural Research Corporation Ministry of Agriculture, Livestock and Supply EMBRAPA (2012). 
Biological Control of Tomato Phytopathogens as an Alternative to Agricultural Defensives and Antibiotics

A survey of 10 selected countries was carried out regarding the registration of products used as a form of biological control in North America, Central America, South America, Europe and 0ceania (Figure 4).

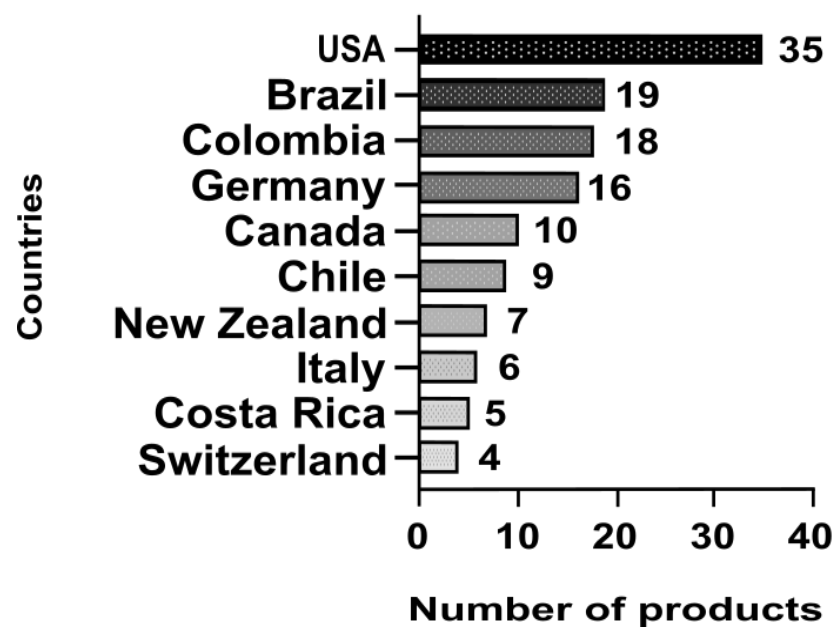

Figure 4 - South America concentrates most of the products used as a form of biological control. Source: The author himself.

According to the data presented in Table 3 and Figure 4, despite the 19 products for biological control registered in Brazil, only three are intended for use in tomato, two of which received only a temporary registration (Figure 5).

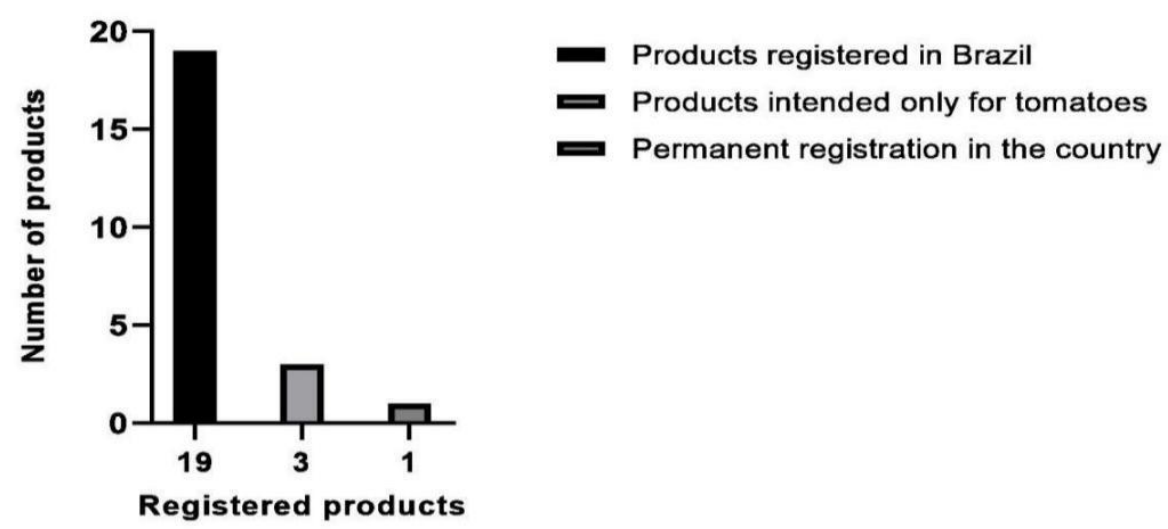

Figure 5 - Products for biological control of tomato diseases in Brazil. Source: The author himself.

After a careful analysis of the 40 articles selected for the composition of this review article, the main agricultural defensives and the main strains of biological agents used by producers were selected. Finally, the search for keywords in the selected articles resulted in greater frequency for products based on copper, DDT, pyraclostrobin, and mancozeb as the main agricultural defensives used in the chemical control of tomato (Tabela 4). 
Table 4 - Main chemical and biological products used to control tomato diseases

\begin{tabular}{|c|c|}
\hline Agricultural defensives & References \\
\hline Copper oxychloride * & $\begin{array}{l}\text { ITAKAR0 et al., 2015; VEIGA et al., 2006; } \\
\text { ARNOLD et al., } 2004 \text {. }\end{array}$ \\
\hline Dichloro-diphenyl-trichloroethane (DDT) * & $\begin{array}{l}\text { OLISAH } \text { et al., 2020; MEFTAUL et al., 2020; } \\
\text { WILSON; TISDELL, 2001; VEIGA et al., 2006; } \\
\text { BHANDARI et al., 2020. }\end{array}$ \\
\hline Pyraclostrobin * & ITAKAR0 et al., 2015. \\
\hline Mancozeb * & ENGINDENIZ, 2006; CALDAS et al., 2000. \\
\hline Diazinon & $\begin{array}{l}\text { ENGINDENIZ, 2006; MEFTAUL et al., 2020; } \\
\text { CALDAS et al., } 2000 .\end{array}$ \\
\hline Dieldrin & $\begin{array}{l}\text { OLISAH et al., 2020; WILSON; TISDELL, } \\
2001 .\end{array}$ \\
\hline Dimethoate & $\begin{array}{l}\text { ENGINDENIZ, 2006; CALDAS et al., 2000; } \\
\text { ANDRADE et al., } 2015 .\end{array}$ \\
\hline Heptachlor & OLISAH et al., 2020; OROZCO et al., 2017. \\
\hline Hexachlorocyclohexane & OLISAH et al., 2020; MEFTAUL et al., 2020. \\
\hline Biological control agent & References \\
\hline $\begin{array}{l}\text { Bacillus spp. } \\
\text { LAB }\end{array}$ & $\begin{array}{l}\text { SHODA et al., } 2000 . \\
\text { MARIN et al., } 2019 .\end{array}$ \\
\hline
\end{tabular}

In this research, the main strains of phytopathogens causing disease in tomatoes were Xanthomonas perforans, X. gardneri, X. vesicatoria, X. euvesicatoria, responsible for causing the bacterial spot (BLAINSKI et al., 2018), Ralstonia spp. causing soft rot and Clavibacter michiganensis subsp. michiganensis with seed infection (YENDYO; RAMESH; PANDEY, 2017), (Figure 6).

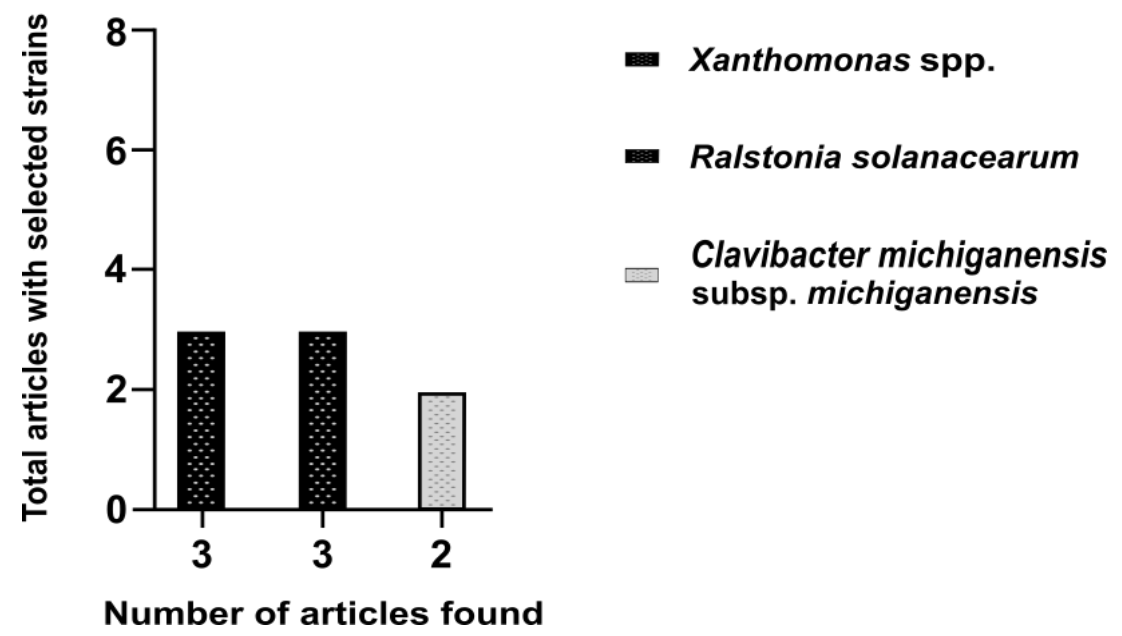

Figure 6 - Main strains of bacteria reported to cause diseases in tomato. Source: The author himself.

According to published studies, only two articles reported the use of phages as a means of biological control of tomato diseases (ADDY et al., 2012; WANG et al., 2019). 

Antibiotics

The detrimental effect of exacerbating use of agricultural defensives has been one of the most relevant topics discussed worldwide in recent decades (MEFTAUL et al., 2019). These chemical compounds used on a large scale in agriculture can be displaced over long distances from the place firstly sprayed, affecting the environment, domestic animals, the wild, and also to humans, requiring studies on the effects and toxicological interactions between man, environment, and these compounds (OLISAH; OKOH 0; OKOH I, 2020).

Thus, these agricultural defensives receive a certain toxicological classification according to the regulatory body of each country, in Brazil ANVISA is responsible for the classification related to humans (Table 1) and the Brazilian Institute for the Environment and Renewable Natural Resources (IBAMA) is responsible for research on toxicity to the environment (UYEMURA et al., 2017; ANVISA, 2019). Worldwide, WH0 classifies these products based on LD50 in rats, oral and dermal, per $\mathrm{mg} / \mathrm{kg}$ of weight of liquid and solid formulations, according to the data provided by the manufacturer and, if it is not possible to obtain these data from classification is carried out in proportion to the LD50 values (BONVOISIN et al., 2020). In an attempt to standardize the use of various forms of controls, protocols were created, according to the following formula according to WHO (2019).

$\frac{L D^{50} \text { active compound } \times 100}{\text { percentage of active compound in the formulation }}$

*The LD50 value is a statistical estimate of the number of $\mathrm{mg}$ of toxic per $\mathrm{kg}$ of body weight required to harvest $50 \%$ of a certain population of test animals.

In the case of formulas containing more than one chemical product (active ingredient, solvents, etc.), if the toxicity of the final product increases, the toxicological classification should represent the total of that combination (WH0, 2019), as is the case with some agricultural defensives shown in Table 2.

The regulation of these products is important because a large part of the agricultural defensives used by rural producers offer a high degree of toxicity as can be seen in Table 2 and Figure 3. In their studies, Engindeniz (2005) reports that in Turkey some tomato farmers make use of disproportionate amount of agricultural defensives for fear of losing the crop. The main agricultural defensives reported in this study were hydrogen oxalate (Evisect), lambda cyhalothrin (Karate), imidacloprid (Confidor), dimethoate (Poligor), basudin 60 EM (Diazinon), propineb (Antracol), metalaxyl mancozeb (Ridomil), trifluralin (Treflan) and abamectin (Agrimec). According to WHO (2019). They represent a high degree of toxicity, and their use, even 
if controlled or mainly indiscriminate, can put the lives of people, animals and the environment at risk (OLISAH; OKOH; OKOH, 2020). A viable alternative is the use of biological control (KONDOH; HIRAI; SHODA, 2000).

Another relevant factor is the use of products that have already been banned and are still commercialized due to their relatively cheap price, as is the case with carbendazim and dietofencarb (LI et al. 2016), dichlorodiphenyltrichloroethane (DDT) and, the hexachlorocyclohexane isomers banned from India and other Asian countries (MEFTAUL et al. 2019), and methyl bromide that was expected to be banned by 2005 according to the Montreal protocol for causing depletion in the ozone layer (SANDE et al., 2011).

Similarly, small producers and equipment operators believe that the exacerbated use of low-quality agricultural defensives, generally because they are cheaper, generates better results (Quirós et al. 2017), however, these products can cause problems such as burns, skin irritation, vomiting, and headaches, being reported in more than half of the interviewees by the group of (NÁJERA et al. 2011), and almost all, when suffering some intoxication in the field, consumed lemon juice or milk as an antidote form.

This data is important because the technical level of the producer and workers can reflect on severe environmental, occupational and comorbidities that go beyond the communities where a product is generated, putting at risk the families that participate in the production process and also to other consumers. In this way, part of the environmental impact and products with a high degree of toxicity can be mitigated by offering training to farmers, using good agricultural practices and eliminating or reducing products from the most toxic classes (ARAÚJO; NOGUEIRA; AUGUST0, 2000).

Despite the existence of products that less toxic to human health (class IV), agricultural defensive copper-based with a large spectrum action identified in Table 2, possesses a significant impact on the environment, thus according to the studies of Arnold et al. (2004), and Meftaul et al. (2019), copper is toxic to embryos of certain aquatic animals can impair marine life, cause urothelial carcinoma in dogs, poisoning of birds and non-target insect death due to misuse.

Although most farmers choose to use chemicals such as agricultural defensives and antibiotics, there are other products aimed at the numerous diseases in tomato crops and less aggressive to producers and consumers, the use of live microorganisms as a form of biological control in certain cases are as efficient as chemical control, therefore the use of these compounds is not always justified and, despite the reduced number of biological products 
Biological Control of Tomato Phytopathogens as an Alternative to Agricultural Defensives and Antibiotics

compared to agricultural defensives, there are several alternatives aimed only at tomato, as can be seen in Table 3.

The utilization of Rhizobacteria and Bacillus sp. used as biological control of bacterial wilt caused by Ralstonia solanacearum (YAMAM0T0 et al., 2015; WU et al., 2016), and other pathogens had results proportional to the chemical inducer acibenzolar-S-methyl resistance (ASM) reported by Rocha; Moura, (2013), and Itakaro and collaborators (2015), as being efficient in the combat to strains of the genus Xanthomonas. Corroborating with these data, Marin et al. (2019) report the use of lactic acid bacteria (LAB), Serenade® OPTI-BAYER (a single strain of Bacillus subtilis strain QST 713), and AgriPhage тм (Bacteriophage) as microorganisms successfully used against various Xanthomonas pathovars.

Therefore, although solutions based on biological control are smaller than formulations based on agricultural defensives (Table 4), there are several products in other countries (Figure 4) that present good alternatives for important tomato pathogens (Figure 6). In Brazil, there are few registered products aimed only at combating tomato diseases (Figure 5). Although most of the data point to tests carried out "in vitro" like those of Rocha; Moura, (2013), biological control is still feasible because, according to Duval et al. (2003), and Itako et al. (2015) use of certain types of agricultural defensives such as copper derivatives and antibiotics such as streptomycin and oxytetracycline do not always offer satisfactory control of the disease or pathogen such as Xanthomonas spp. which can result in the selection of resistant bacterial isolates.

\section{CONCLUSION}

The cultivation of tomato represents great economic value for several countries, having a wide range of derived products however, some cultivated species are susceptible to diverse pathogens. Therefore, most of the treatment of diseases is realized through products such as agricultural defensives and antibiotics.

In this work, the agricultural defensives most reported by producers were Copper oxychloride, products derived from DDT, Pyraclostrobin, and Mancozeb, all belonging to the most toxic class. For the antibiotics class, Streptomycin and 0xytetracycline have been reported are mostly used. The biological control agents most cited in this work were lactic acid bacteria and Bacillus spp., only two studies reported the use of bacteriophages as a form of biological control.

Regarding the toxicity caused to humans and the environment, some agricultural defensives have been associated with contamination of marine life, the appearance of different 
types of cancer in humans and domestic animals, and depletion of the ozone layer. Antibiotics have been linked to the emergence of resistant bacterial isolates and water contamination through residues. Some biological control agents have been reported to have similar efficacy to certain chemicals. No data were found related to toxicity in humans and animals by antibiotics or biological control agents. Response speed data to treatment haven't been evaluated in comparison to chemical products.

Finally, more studies "in vivo" are needed about biological control agents for better decision-making by producers, in addition to better agricultural practices such as the nonutilization of agricultural defensives banned from the market and better planning, countries like Indonesia, Holland, and Guatemala are examples of the fact that biological control agents can serve as an alternative or decrease in chemical products.

\section{ACKNOWLEDGMENTS}

Rodolfo Sodré Tavares, Paulo Alex Neves da Silva, Ludmila Batista Machado, Abadia dos Reis Nascimento and Lilian Carla Carneiro developed the theoretical formalism, compilation the data, graphics and performed the numerical simulations. All the authoers contribuited to the final version of the manuscript. José Daniel Gonçalves Vieira supervised the project.

\section{REFERENCES}

ADDY, H. S.; ASKORA, A.; KAWASAKI, T.; FUJIE, M.; YAMADA, T. Utilization of filamentous phage $\varphi$ RSM3 to control bacterial wilt caused by Ralstonia solanacearum. Plant Disease, v.96, n.8, p.1204-1209, 2012. Available from: 〈https://pubmed.ncbi.nlm.nih.gov/30727062/>. Accessed: JUN. 6, 2020. doi: 10.1094/PDIS-12-11-1023-RE.

AGROFIT. Sistema de agrotóxicos fitossanitários. Available from: <http://agrofit.agricultura.gov.br/agrofit_cons/principal_agrofit_cons $>$ Accessed: JUN. 6, 2020.

ANDRADE, G. C. R. M.; MONTEIRO, S. H.; FRANCISCO, J. G.; FIGUEIREDO, L. A.; ROCHA, A. A.; TORNISIELO, V. L. Effects of types of washing and peeling in relation to pesticide residues in tomatoes. Journal of the Brazilian Chemical $\begin{array}{llllll}\text { Society, } & \text { v.26, } & \text { n.10, } & \text { p.1994-2002, } & \text { Available } & \text { from: }\end{array}$ <https://www.scielo.br/scielo.php?script=sci_arttext\&pid=S0103-50532015001001994〉. Accessed: JUN. 6, 2020. doi: 10.5935/0103-5053.20150179J.

ANVISA. Agência Nacional de Vigilância Sanitária. Resolução da Diretoria Colegiada - RDC Nº 294, de 29 de julho de 2019. Critérios para avaliação e classificação toxicológica - AG0. 8, 2020. Available from: 〈https://www.gov.br/anvisa/pt-br\#/visualizar/403290〉.

ANVISA. Agência Nacional de Vigilância Sanitária. RESOLUÇÃo DA DIRETORIA COLEGIADA - RDC No 296, DE 29 DE JULHO DE 2019. Critérios para avaliação e classificação toxicológica - MAY. 8, 2021. Available from: <https://www.documentador.pr.gov.br/documentador/pub.do?action=d\&uuid=@gtf-escriba-sesa@60e765743f03-4289-a2f2-f2ef36ldb6dl\&emPg=true>. 
ARAÚJ0, A. C. P.; NOGUEIRA, D. P.; AUGUST0, L. G. S. Impacto dos praguicidas na saúde: Estudo da cultura de tomate. Revista de Saúde Pública, v.34, n.3, p.309-313, 2000. Available from:<https://www.scielo.br/scielo.php?pid=S003489102000000300016 sscript=sci_abstractotlng=pt $>$ Accessed: $\quad$ JUN. $\quad 6, \quad 2020$. doi: 10.1590/S003489102000000300016 .

ARNOLD, G. L.; LUCKENBACH, M. W.; UNGER, M. A. Runoff from tomato cultivation in the estuarine environment: Biological effects of farm management practices. Journal of Experimental Marine Biology and Ecology, v.298, n.2, p.323-346, 2004. Available from: <https://www.sciencedirect.com/science/article/pii/S0022098103003666?via\%3Dihub〉. Accessed: JUN. 6, 2020. doi: 10.1016/S0022-0981(03)00366-6.

BETTIOL, W.; MORANDI, M. A. B.; PINTO, Z. V.; JÚNIOR, T. J. P.; CORRÊA, E. B.; MOURA, A. B.; LUCON, C. M. M.; COSTA, J. C. B.; BEZERRA, J. L. Produtos comerciais à base de agentes de biocontrole de doenças de plantas. Embrapa Meio Ambiente (Documentos 88). 2012. 156p.

BHANDARI, G.; ATREYA, K.; SCHEEPERS, P. T. J.; GEISSEN, V. Concentration and distribution of pesticide residues in soil: Non-dietary human health risk assessment. Chemosphere, v.253, p.1-13, 2020. Available from: <https://pubmed.ncbi.nlm.nih.gov/32289601/>. Accessed: JUN. 6, 2020. doi: 10.1016/j.chemosphere.2020.126594.

BLAINSKI, J. M. L.; NETO, A. C. R.; SCHIMIDT, E. C.; VOLTOLINI, J. A.; ROSSI, M. J.; PIERO, R. M. Exopolysaccharides from Lactobacillus plantarum induce biochemical and physiological alterations in tomato plant against bacterial spot. Applied Microbiology and Biotechnology, v.102, n.11, p.4741-4753, 2018. Available from: <https://pubmed.ncbi.nlm.nih.gov/29656378/>. Accessed: JUN. 6, 2020. doi: 10.1007/s00253-018-8946-0.

BONVOISIN, T.; UTYASHEVA, L.; KNIPE, D.; GUNNEL, D.; EDDLESTON, M. Suicide by pesticide poisoning in India: a review of pesticide regulations and their impact on suicide trends. BMC Public Health, v.20, p.1-16, 2017. Available from: <https://www.ncbi.nlm.nih.gov/pmc/articles/PMC7031890/>. Accessed: MAY. 5, 2021. 10.1186/s12889-020-8339-z.

CALDAS, E. D.; SOUZA, L. C. K. Chronic dietary risk assessment for pesticide residues in Brazilian food. Journal of public health, v.34, n.5, p.529-537, 2000. Available from: 〈https://pubmed.ncbi.nlm.nih.gov/15764334/>. Accessed: JUN. 6, 2020. doi: 10.1080/02652030400009225.

CASTRO, I. M.; BRANDÃO, E. S.; MACED0, J. R. Aspectos funcionais e nutricionais do tomate Uso de agrotóxicos na tomaticultura de São José de Ubá (RJ), Embrapa Agroindústria de Alimentos (Documentos 95) p. 1-32, 2008.

DUVAL, A. M. Q.; FILHO, A. G.; JÚNIOR, R. P. L.; CAMARGO, L. E. A. Sensibilidade a cobre, estreptomicina e oxitetraciclina em Xanthomonas spp. associadas à mancha-bacteriana do tomate para processamento industrial. Horticultura Brasileira, v.21, n.4, p.15-24, 2003. Available from: <https://www.scielo.br/scielo.php?script=sci_arttext\&pid=S010205362003000400020>. Accessed: JUN. 6, 2020. doi: https://doi.org/10.1590/S0102-05362003000400020.

ENGINDENIZ, S. Economic analysis of pesticide use on processing tomato growing: A case study for Turkey. CROP PROTECTI0N, $\quad$ v.25, n.6, p.534-541, $2006 . \quad$ Available $\quad$ from: 〈https://www.sciencedirect.com/science/article/abs/pii/S02612194050022675〉. Accessed: JUN. 6, 2020. doi: 10.1016/j.cropro.2005.08.009.

FA0 - FAOSTAT - Food and Agriculture Organization of the United Nations. Available from: <http://faostat.fao.org/>. Accessed: ABR. 4, 2020.

GE, B.; LIU, B.; NWET, T. T.; ZHA0, W.; SHI, L.; ZHANG, K. Bacillus methylotrophicus strain NKG-1, Isolated from changbai mountain, China, Has potential applications as a biofertilizer or biocontrol agent. PLOS 0NE, v. 11, n.11, p.1-13, 2016. Available from: <https://pubmed.ncbi.nlm.nih.gov/27832162/>. Accessed: JUN. 6, 2020. doi: 10.1371/journal.pone.0166079.

GUIMARÃES, A.; SANTIAG0, A.; TEIXEIRA, J. A.; VENÂNCIO, A.; ABRUNHOSA, L. Anti-aflatoxigenic effect of organic acids produced by Lactobacillus plantarum. International Journal of Food Microbiology, v.264, p.31-38, 2018. Available from: <https://pubmed.ncbi.nlm.nih.gov/29107194/>. Accessed: JUN. 6, 2020. doi: 10.1016/j.ijfoodmicro.2017.10.025.

ITAKO, A. T.; JÚNIOR, J. B. T.; JÚNIOR, T. A. F. S.; SOMAN, J. M.; MARING0NI, A. C. Chemical products induce resistance to Xanthomonas perforans in tomato. Brazilian Journal of Microbiology, v.46, n.3, p.701-706, 2015. Available from: <https://pubmed.ncbi.nlm.nih.gov/26413050/>. Accessed: JUN. 6, 2020. doi: 10.1590/S1517-838246320140177. 
IZZEDDIN, N. A.; MEDINA, L. T. Efecto del control biológico por antagonistas sobre fitopatógenos en vegetales de

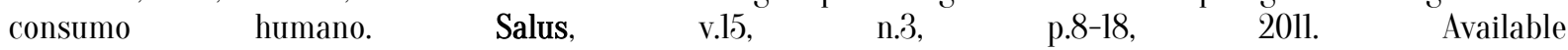
from:〈http://ve.scielo.org/scielo.php?script=sci_arttext\&pid=S1316-71382011000300005>. Accessed: JUN. 6, 2020.

KONDOH, M.; HIRAI, M.; SHODA, M. Integrated biological and chemical control of damping-off caused by Rhizoctonia solani using Bacillus subtilis RB14-C and flutolanil. Journal of Bioscience and Bioengineering, v.91, n.2, p.173-177, 2001. Available from: <https://pubmed.ncbi.nlm.nih.gov/16232970/05>. Accessed: JUN. 6, 2020. doi: 10.1016/Sl3891723(01)80061-x.

LI, H.; DU, H.; FANG, L.; DONG, Z.; GUAN, S.; FAN, W.; CHEN, Z. Residues and dissipation kinetics of carbendazim and diethofencarb in tomato (Lycopersicon esculentum Mill.) and intake risk assessment. Regulatory Toxicology and $\begin{array}{llll}\text { Pharmacology, } & \text { v.77, } & \text { p.200-205, } & \text { Available }\end{array}$ from:〈https://www.sciencedirect.com/science/article/abs/pii/S0273230016300563?via\%3Dihub〉. Accessed: JUN. 6, 2020. doi: 10.1016/j.yrtph.2016.03.012.

MARIN, V. R.; FERRAREZI, J. H.; VIEIRA, G.; SASS, D. C. Recent advances in the biocontrol of Xanthomonas spp. World Journal of Microbiology and Biotechnology, v.35, n.5, p.1-7, 2019. Available from: <https://pubmed.ncbi.nlm.nih.gov/31011844/>. Accessed: JUN. 6, 2020. doi: 10.1007/s11274-019-2646-5.

MEFTAUl, I.; VENKATESWARlU, K.; DHARMARAJAN, R.; ANNAMALAI, P.; MEGHARAJ, M. Pesticides in the urban environment: A potential threat that knocks at the door, Science of the Total Environment, v.711, p.1-55, 2019. Available from: 〈https://pubmed.ncbi.nlm.nih.gov/31810707/>. Accessed: JUN. 6, 2020. doi: 10.1016/j.scitotenv.2019.134612.

NÁJERA, R. E. R.; NÁJERA, J. A. R.; GONZALEZ, S. G.; LUNA, E. J. P. Manejo y control de plagas del cultivo de tomate en Cintalapa, Chiapas, Mexico. Revista Internacional de Contaminacion Ambiental, v.27, n.2, p. 129-137, 2011. Available from: <http://www.scielo.org.mx/scielo.php?script=sci_arttext\&pid=S0188-49992011000200004〉. Accessed: JUN. 6, 2020.

OLISAH, C.; OKOH, 0. 0.; OKOH, A. I. Occurrence of organochlorine pesticide residues in biological and environmental matrices in Africa: A two-decade review. Heliyon, v.6, n.3, p.1-25, 2020. Available from: 〈https://www.sciencedirect.com/science/article/pii/S2405844020303637〉. Accessed: JUN. 6, 2020. doi: 10.1016/j.heliyon.2020.e03518.

OROZCO, F. D. A.; GALLÓN, L. M. L.; FANDIÑO, M. I. P.; OROZCO, A. L.; CIFUENTES, J. A. G. Phytosanitary residuality in tomato and cape gooseberry grown in Quindío (Colômbia). Corpoica Ciencia y Tecnología Agropecuaria, v.18, n3, p.571-582, 2017. Available from: <http://www.scielo.org.co/scielo.php?script=sci_arttext\&pid=S012287062017000300571६lang=pt>. Accessed: JUN. 6, 2020. doi: 10.21930/rcta.voll8_num3_art:745.

QUIRÓS, A. D.; LUTZ, M. I. G.; HERNÁNDEZ, G. V.; ACEDO, D. M. Situaciones de riesgo potencial relacionadas con la aplicación de agroquímicos en los sistemas hortícolas. Agronomía Costarricense, v.41, n.2, p.67-77, 2017. Available from: $<$ https://www.scielo.sa.cr/scielo.php?script=sci_arttext\&pid=S0377-94242017000200067\&lang=pt $>$. Accessed: JUN. 6, 2020. doi: 10.15517/rac.v4li2.31300.

ROCHA, D. J. A.; MOURA, A. B. Controle biológico da murcha do tomateiro causada por Ralstonia solanacearum e Fusarium oxysporum f. sp. lycopersici por rizobactérias. Tropical Plant Pathology, v.38, n.5, p.423-430, 2013. Available from: 〈https://www.scielo.br/scielo.php?pid=S1982-56762013000500007\&script=sci_abstract\&tlng=pt . Accessed: JUN. 6, 2020. doi: https://doi.org/10.1590/S1982-56762013005000025.

SANDE, D.; MULLEN, J.; WETZSTEIN, M.; HOUSTON, J. Environmental impacts from pesticide use: A case study of soil fumigation in Florida tomato production. International Journal of Environmental Research and Public Health, v.8, n.12, p.4649-4661, 2011. Available from: <https://www.ncbi.nlm.nih.gov/pmc/articles/PMC3290991/>. Accessed: JUN. 6, 2020. doi: 10.3390/ijerph8124649.

SHOKRYAZDAN, P.; JAHROMI, M. F.; LIANG, J. B.; HO, Y. W. Probiotics: From Isolation to Application. Journal of the American College of Nutrition, v.36, n.8, p.666-676, 2017. Available from: <https://pubmed.ncbi.nlm.nih.gov/28937854/>. Accessed: JUN. 6, 2020. doi: 10.1080/07315724.2017.1337529. 
SILVA, P. A. N.; ITO, C. R.; BARBOSA, M. S.; SANTOS, M. 0.; CARNEIR0, L. C. Arboviruses (chikungunya, dengue, and Zika) associated with ophthalmic changes: a focus on aqueous fluid and vitreous humor. European Journal of Clinical Microbiology \& Infectious Diseases, v.39, n.5, p.827-833, 2019. Available from: <https://pubmed.ncbi.nlm.nih.gov/31863236/>. Accessed: JUN. 2, 2020. doi: 10.1007/s10096-019-03792-9.

SOLANKI, M. K.; SINGH, R. K.; SRIVASTAVA, S.; KUMAR, S.; KASHYAP, P. L.; SRIVASTAVA, A. K. Characterization of antagonistic-potential of two Bacillus strains and their biocontrol activity against Rhizoctonia solani in tomato. Journal of Basic Microbiology, v.55, n.1, p.82-90, 2015. Available from: 〈https://pubmed.ncbi.nlm.nih.gov/24277414/>. Accessed: JUN. 6, 2020. doi: 10.1002/jobm.201300528.

UYEMURA, S. A.; STOPPER, H.; MARTIN, F. L.; KANNEN, V. A Perspective Discussion on Rising Pesticide Levels and Colon Cancer Burden in Brazil. Frontiers in public health, v.5, p.1-8, 2017. Available from: 〈https://www.ncbi.nlm.nih.gov/pmc/articles/PMC5650604/〉. $\quad$ Accessed: $\quad$ MAY. $\quad 5,2021$. doi:10.3389/fpubh.2017.00273.

VEIGA, M. M.; SILVA, D. M.; VEIGA, L. B. E.; FARIA, M. V. C. Análise da contaminação dos sistemas hídricos por agrotóxicos numa pequena comunidade rural do Sudeste do Brasil. Cadernos de saúde pública, v.22, n.11, p.23912399, 2006. Available from: 〈https://www.scielo.br/scielo.php?pid=S0102-311X2006001100013\&script=sci_abstract $>$. Accessed: JUN. 6, 2020. doi: 10.1590/s0102-311x2006001100013.

WANG, X.; WEI, Z.; YANG, K.; WANG, J.; JOUSSET, A.; XU, Y.; SHEN, Q.; FRIMAN, V. P. Phage combination therapies for bacterial wilt disease in tomato. Nature Biotechnology, v.37, n.12, p.1513,1520, 2019. Available from: <https://pubmed.ncbi.nlm.nih.gov/31792408/>. Accessed: JUN. 6, 2020. doi: 10.1038/s41587-019-0328-3.

WILSON, C.; TISDELL, C. Why farmers continue to use pesticides despite environmental, health and sustainability costs. Ecological Economics, v.39, n.3, p.449-462, 2001. Available from: <https://www.sciencedirect.com/science/article/abs/pii/S0921800901002385〉. Accessed: JUN. 6, 2020. doi: 10.1016/S0921-8009(01)00238-5.

WORLD HEALTH ORGANIZATION. The Who recommended clasification of pesticides by hazard. Switzerland: WH0; 2019. Available from: <https://www.who.int/publications/i/item/9789240005662〉. Accessed: AG0. 8, 2020.

WU, K.; FANG, Z.; WANG, L.; YUAN, S.; GU0, R.; SHEN, B.; SHEN, Q. Biological potential of bioorganic fertilizer fortified with bacterial antagonist for the control of tomato bacterial wilt and the promotion of crop yields. Journal of Microbiology and Biotechnology, v.26, n.10, p.1755-1764, 2016. Available from: <https://pubmed.ncbi.nlm.nih.gov/27381335/>. Accessed: JUN. 6, 2020. doi: 10.4014/jmb.1604.04021.

XU, X.; KUMAR, A.; DEBLAIS, L.; MIMBELA, R. P.; NISLOW, C.; FUCHS, J. R.; MILLER, S. A.; RAJASHEKARA, G. Discovery of novel small molecule modulators of Clavibacter michiganensis subsp. Michiganensis. Frontiers in Microbiology, v.6, p.1-10, 2015. Available from: 〈https://pubmed.ncbi.nlm.nih.gov/26539169/>. Accessed: JUN. 6, 2020. doi: 10.3389/fmicb.2015.01127.

YAMAMOTO, S.; SHIRAISHI, S.; KAWAG0E, Y.; MOCHIZUKI, M.; SUZUKI, S. Impact of Bacillus amyloliquefaciens Sl3-3 on control of bacterial wilt and powdery mildew in tomato. Pest Management Science, v.71, n.5, p.722-727, 2015. Available from: <https://pubmed.ncbi.nlm.nih.gov/24889125/>. Accessed: JUN. 6, 2020. doi: 10.1002/ps.3837.

YENDYO, S.; RAMESH, G. C.; PANDEY, B, R. Evaluation of Trichoderma spp., Pseudomonas fluorescence and Bacillus subtilis for biological control of Ralstonia wilt of tomato. F1000Research, v.6, p.1-10, 2017. Available from: <https://pubmed.ncbi.nlm.nih.gov/29560253/>. Accessed: JUN. 6, 2020. doi: 10.12688/f1000research.12448.3.

ZAVATTI, L. M. S.; ABAKERLI, R. B. Resíduos de agrotóxicos em frutos de tomate. Pesquisa Agropecuária Brasileira, v.34, n.3, p.473-480, 1999. Available from: <https://www.scielo.br/scielo.php?script=sci_arttext\&pid=S0100204X1999000300020>. Accessed: JUN. 6, 2020. doi: 10.1590/s0100-204x1999000300020. 